\title{
Recurrent belly dancer dyskinesia in pregnancy
}

Supplemental data at Neurology.org
A 37-year-old woman in her 34th week of pregnancy developed continual abdominal movements, which had complicated both her previous pregnancies (video at Neurology.org). Examination, routine bloodwork, and brain MRI were normal. Circumstances precluded prepartum thoracolumbar MRI; postpartum MRI was unrevealing. Clonazepam and levetiracetam suppressed the movements, which remitted postpartum. All babies were healthy.

Recurrent abdominal dyskinesia in pregnancy, reported once before, ${ }^{1}$ perhaps results from local compressive or hemodynamic changes in the thoracic cord or roots from the gravid uterus. Similar mechanisms also could account for abdominal myoclonus in pregnancy. ${ }^{2}$ Hormonal effects (akin to chorea gravidarum) seem less plausible given the focality of the dyskinesia.

Jenny A. Meyer, MD, Kunal V. Desai, MD, Howard L. Geyer, MD, PhD

From Albert Einstein College of Medicine, The Saul R. Korey Department of Neurology at Montefiore Medical Center, Bronx, NY. Author contributions: Dr. Meyer: drafting/revising the manuscript, reviewed literature, and accepts responsibility for conduct of research and final approval. Dr. Desai: drafting/revising the manuscript, accepts responsibility for conduct of research and final approval, and acquisition of data. Dr. Geyer: drafting/revising the manuscript, aiding in study concept and design, interpretation of case, and accepts responsibility for conduct of research and final approval.

Study funding: No targeted funding reported.

Disclosure: The authors report no disclosures relevant to the manuscript. Go to Neurology.org for full disclosures.

Correspondence to Dr. Meyer: jejohnso@montefiore.org

1. Herbert J, Hassanaien M. Case Study: A Belly-dancing Womb. Presented at the Royal College of Obstetricians and Gynaecologists World Congress; March 30, 2014; Hyderabad, India.

2. Yerdelen D, Karatas M, Aslan E, et al. Spinal segmental myoclonus related to pregnancy. Acta Neurol Belg 2007;107:11-13.

\section{WriteClick ${ }^{\circledR}$ rapid online correspondence}

The editors encourage comments about recent articles through WriteClick:

Go to Neurology.org and click on the "WriteClick" tab at the top of the page. Responses will be posted within 72 hours of submission.

Before using WriteClick, remember the following:

- WriteClick is restricted to comments about studies published in Neurology within the last eight weeks

- Read previously posted comments; redundant comments will not be posted

- Your submission must be 200 words or less and have a maximum of five references; reference one must be the article on which you are commenting

- You can include a maximum of five authors (including yourself) 


\title{
Neurology
}

\author{
Recurrent belly dancer dyskinesia in pregnancy \\ Jenny A. Meyer, Kunal V. Desai and Howard L. Geyer \\ Neurology 2017;88;2066 \\ DOI 10.1212/WNL.0000000000003954
}

This information is current as of May 22, 2017

\begin{tabular}{|c|c|}
\hline $\begin{array}{l}\text { Updated Information \& } \\
\text { Services }\end{array}$ & $\begin{array}{l}\text { including high resolution figures, can be found at: } \\
\text { http://n.neurology.org/content/88/21/2066.full }\end{array}$ \\
\hline Supplementary Material & $\begin{array}{l}\text { Supplementary material can be found at: } \\
\text { http://n.neurology.org/content/suppl/2017/05/22/WNL.0000000000003 } \\
\text { 954.DC1 }\end{array}$ \\
\hline References & $\begin{array}{l}\text { This article cites } 1 \text { articles, } 0 \text { of which you can access for free at: } \\
\text { http://n.neurology.org/content/88/21/2066.full\#ref-list- } 1\end{array}$ \\
\hline Subspecialty Collections & $\begin{array}{l}\text { This article, along with others on similar topics, appears in the } \\
\text { following collection(s): } \\
\text { All Movement Disorders } \\
\text { http://n.neurology.org/cgi/collection/all_movement_disorders } \\
\text { Clinical neurology examination } \\
\text { http://n.neurology.org/cgi/collection/clinical_neurology_examination } \\
\text { Clinical neurology history } \\
\text { http://n.neurology.org/cgi/collection/clinical_neurology_history }\end{array}$ \\
\hline Permissions \& Licensing & $\begin{array}{l}\text { Information about reproducing this article in parts (figures,tables) or in } \\
\text { its entirety can be found online at: } \\
\text { http://www.neurology.org/about/about_the_journal\#permissions }\end{array}$ \\
\hline Reprints & $\begin{array}{l}\text { Information about ordering reprints can be found online: } \\
\text { http://n.neurology.org/subscribers/advertise }\end{array}$ \\
\hline
\end{tabular}

Neurology ${ }^{\circledR}$ is the official journal of the American Academy of Neurology. Published continuously since 1951, it is now a weekly with 48 issues per year. Copyright (O 2017 American Academy of Neurology. All rights reserved. Print ISSN: 0028-3878. Online ISSN: 1526-632X.

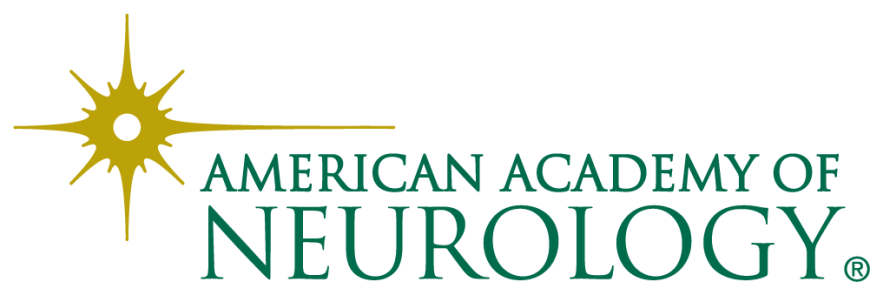

